\title{
PERENCANAAN SISTEM PEMANFAATAN AIR HUJAN SEBAGAI AIR SIAP MINUM DI KANTOR DINAS PENDIDIKAN PROVINSI DKI JAKARTA
}

\author{
Ilham Tri Purnomo ${ }^{1}$, M. Zaky Alfarisi ${ }^{2}$, Mutioro Sukmono ${ }^{3 *}$ \\ ${ }^{1}$ Lulusan Program Studi Teknik Konstruksi Sipil, Jurusan Teknik Sipil, Politeknik Negeri Bandung, Bandung 40012 \\ E-mail : Ilhamtripurwono@gmail.com \\ ${ }^{2}$ Lulusan Program Studi Teknik Konstruksi Sipil, Jurusan Teknik Sipil, Politeknik Negeri Bandung, Bandung 40012 \\ E-mail :emzakal@gmail.com \\ ${ }^{3}$ Dosen Jurusan Teknik Sipil, Politeknik Negeri Bandung, Bandung 40012 \\ *E-mail Penulis Korespondensi : mutioro@polban.ac.id
}

\begin{abstract}
ABSTRAK
Curah hujan yang tinggi di Jakarta merupakan potensi yang luar biasa dan perlu dimanfaatkan. Pemanfaatan air hujan menjadi air siap minum di Gedung Dinas Pendidikan Provinsi DKI Jakarta merupakan sebuah terobosan penerapan konsep bangunan green building di daerah Ibukota DKI Jakarta. Perencanaan diawali dengan menghitung kebutuhan air minum untuk karyawan di kantor dengan kebutuhan air minum sebanyak 480 liter/hari atau 132.480 liter/tahun. Air hujan difilter dua kali untuk memenuhi standar air minum, sehingga air dapat dikonsumsi. Eksisting raw water tank digunakan untuk menampung air baku hasil filter awal (pretreatment). Sistem pengaliran airnya menggunakan sistem gabungan, air dipompakan dari bak penampung menuju rooftank atau reservoir dengan kapasitas volume sebesar $2550 \mathrm{~m} 3$, kemudian air didistribusikan ke lokasi tempat air minum. Pemilihan filter akhir (treatment) dipilih dari perbandingan antara sistem reverses osmosis, sistem depot air minum, dengan sistem dispenser (galon) dan dihasilkan metode reverse osmosis lebih baik dari segi kualitas air serta menguntungkan dari segi ekonomis. Pada tahun ke-2 modal awal yang telah dikeluarkan pada tahun pertama telah kembali. Kemudian pada tahun berikutnya penghematan biaya meningkat. Dibutuhkan biaya keseluruhan pelaksanaan sebesar Rp. 496.636.000,00.
\end{abstract}

Kata Kunci: air hujan, air siap minum, reverse osmosis, water treatment

\section{ABSTRACT}

The high rainfall in Jakarta is a tremendous potential and needs to be exploited. The use of rainwater as ready-to-drink water in the DKI Jakarta Provincial Education Office Building is a breakthrough in implementing the green building concept in the capital city of DKI Jakarta. Planning begins with calculating the need for drinking water for employees in the office with a drinking water requirement of 480 liters / day or 132,480 liters / year. Rainwater is filtered twice to meet drinking water standards, so that water can be consumed. The existing raw water tank is used to fill the raw water from the pretreatment filter. The water drainage system uses a combined system, air is pumped from the reservoir to a roof tank or reservoir with a volume capacity of $2550 \mathrm{~m} 3$, then the air is diverted to a location where water is drunk. Selection of the final filter (treatment) is selected from the comparison between the reverses osmosis system, drinking water depot system, with the dispenser system (gallon) and resulted in a reverse osmosis method that is better in terms of water quality and economical. In year 2, the initial capital that was issued in the first year has returned. Then the following year the repair costs. It takes a total implementation cost of Rp. 496,636,000.00.

Key Word: rainwater, ready-to-drink water, reverse osmosis, water treatment

\section{PENDAHULUAN}

\subsection{Latar Belakang}

Gedung Kantor Dinas Pendidikan Provinsi DKI Jakarta terletak di ibukota Indonesia tepatnya di J1. Jendral Gatot Subroto Kav 40-41 Kuningan Timur. Gedung kantor dengan jumlah 15 lantai dan luas $\pm 20.240 \mathrm{~m} 2$ ini merupakan gedung negara yang pembangunannya harus memenuhi asas dan prinsip kemanfaatan, keselamatan, keselarasan bangunan gedung dengan lingkungan sesuai dengan peraturan Gubernur DKI Nomor 38 Tahun 2012 mengenai konsep green building. Konsep green building yang ada pada peraturan Gubernur DKI Nomor 38 Tahun 2012 masih sedikit diterapkan di DKI Jakarta, salah satunya adalah pemanfaatan air hujan menjadi air siap minum (ARSINUM). Pemanfaatan air hujan ini diambil karena, dari beberapa penelitian menunjukkan bahwa air tanah di Kota Jakarta, telah mengandung kadar $\mathrm{NaCl}$ yang melebihi ambang batas standar, kawasan Monas hingga daerah Kuningan telah menunjukkan instruksi air laut mencapai daerah tersebut. (M. Wahyudi Memed, Kepala 
Balai Konservasi Air Tanah Kementerian ESDM). Kemudian, Air tanah di Jakarta pun telah banyak berkurang akibat pengambilan yang tak terkendali, ribuan pelanggan tidak tercatat mengambil air tanah setiap hari. Oleh karena itu, sesuai dengan peraturan Gubernur DKI Nomor 38 Tahun 2012 mengenai konsep green building, perencanaan sistem pemanfaatan air hujan menjadi air siap minum di lingkungan Gedung Kantor Dinas Pendidikan DKI Jakarta ini merupakan terobosan baru serta perlu dilakukan untuk mengatasi persoalan air dan limbah tersebut.

\subsection{Tujuan}

Tujuan penelitian ini adalah merencanakan sistem pemanfaatan air hujan sebagai air siap minum yang memenuhi kualitas standar air minum untuk dapat dikonsumsi, menguntungkan dari segi ekonomi, serta menghasilkan sistem yang efisien.

\section{METODE}

Metodologi yang digunakan untuk Perencanaan Sistem Pemanfaatan Air Hujan Sebagai Air Siap Minum Di Kantor Dinas Pendidikan Provinsi DKI Jakarta adalah melakukan pencarian referensi yang berkaitan dengan system pemanfaatan air hujan untuk air siap minum, yang akan digunakan di Kantor Dinas Pendidikan DKI Jakarta. Dilanjutkan dengan pengumpulan data terdiri dari dua macam, yaitu data primer dan data sekunder. Pada tahap Analisis Perhitungan Perencanaan dilakukan perhitungan kebutuhan air minum dan ketersediaan air hujan, kemudian membuat gambar desain layout perencanaan sytem pemanfaatan air hujan.

Untuk mengetahui efisiensi dari pemanfaatan air hujan sebagai air siap minum di Kantor Dinas Pendidikan DKI Jakarta, maka dibuat Rencana Anggaran Biaya pengadaan dan operasional kemudian dibandingkan dengan biaya operasional yang sekarang masih digunakan. Berikut adalah diagram alir metode penelitian:

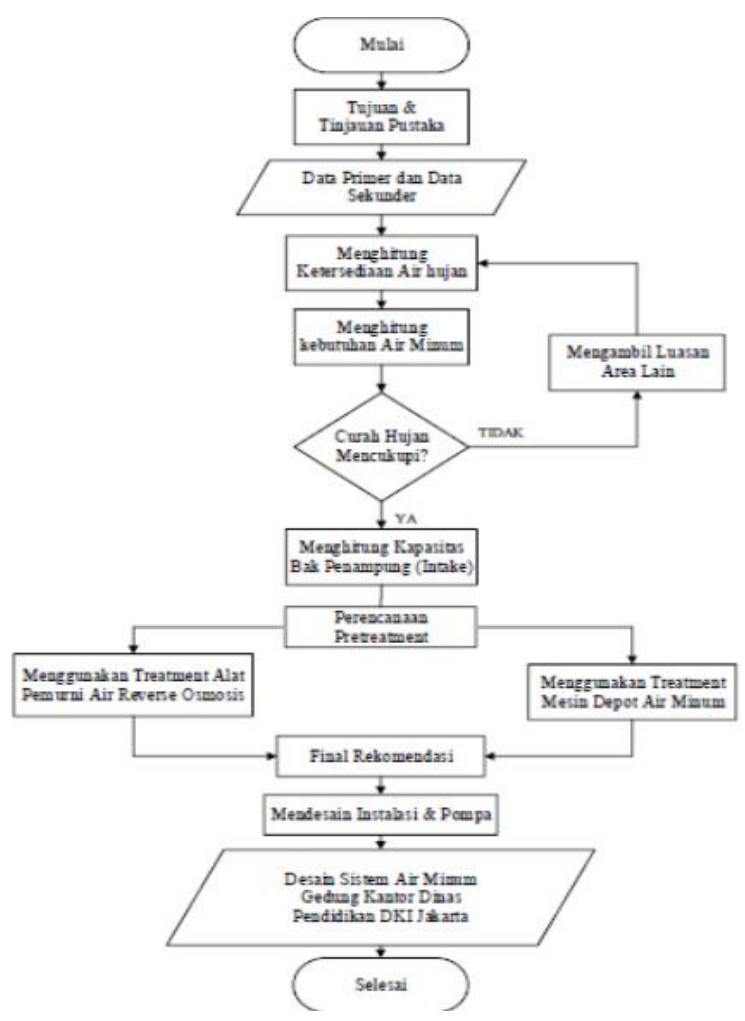

Gambar 1. Diagram Alir Metodologi

\section{HASIL DAN ANALISIS}

\subsection{Perhitungan Kebutuhan Air Minum}

Total staf serta office boy yang bekerja pada kantor dinas Pendidikan DKI Jakarta, sebanyak 400 orang yang, terdiri dari:

1. 385 orang staf.

2. 15 orang office boy. 
Volume kebutuhan air minum (Vdemand) :

Kebutuhan untuk satu hari :

$=$ Kebutuhan air minum dewasa $\times($ Banyaknya jumlah orang kantor $+(10 \%$ di luar pegawai kantor $+10 \%$ orang lembur $))$

$=1$ liter/orang/hari $\times(400$ orang $+(0,2 \times 400$ orang $))$

$=480$ liter $/$ hari $=\mathbf{0 , 4 8} \mathbf{~ m}^{\mathbf{3}} / \mathbf{h a r i}$

Kebutuhan untuk satu bulan :

$=$ Total kebutuhan air minum dalam satu hari $\times$ Hari kerja dalam satu bulan

$=480$ liter/hari $\times(31$ hari -8 hari "weekend" $)$

$=11040$ liter $/$ bulan $=\mathbf{1 1 , 0 4} \mathbf{~ m}^{\mathbf{3}} /$ bulan

Kebutuhan untuk satu tahun :

$=$ Total kebutuhan air minum dalam satu bulan $\times$ Bulan dalam satu tahun

$=11040$ liter $/$ bulan $\times 12$ bulan

$=132480$ liter $/$ tahun $=\mathbf{1 3 2 , 4 8} \mathbf{~ m}^{\mathbf{3}} /$ tahun

\subsection{Perhitungan Suplai Air Hujan}

Data curah hujan dari stasiun Kemayoran selama 10 tahun dapat dilihat pada tabel berikut:

Tabel 1. Data Curah Hujan Per Tahun.

\begin{tabular}{|c|c|c|}
\hline No & Tahun & $\begin{array}{c}\text { curah hujan } \\
\text { jakarta/kemayoran } \\
\text { (mm) }\end{array}$ \\
\hline 1 & 2009 & 1909,0 \\
\hline 2 & 2010 & 1973,0 \\
\hline 3 & 2011 & 2395,0 \\
\hline 4 & 2012 & 1274,1 \\
\hline 5 & 2013 & 1488,2 \\
\hline 6 & 2014 & 2528,1 \\
\hline 7 & 2015 & 2906,7 \\
\hline 8 & 2016 & 2168,6 \\
\hline 9 & 2017 & 2711,5 \\
\hline 10 & 2018 & 2152,0 \\
\hline \multicolumn{2}{|c|}{ Jumlah (n) } & 21506,4 \\
\hline \multicolumn{3}{|c|}{ Sumber: BMRG St. Kemayoran } \\
\hline
\end{tabular}

Berdasarkan data bangunan yang didapatkan, luas atap dengan jenis dak beton pada gedung kantor memiliki luas $768 \mathrm{~m}^{2}$, dapat dilihat pada Gambar berikut.

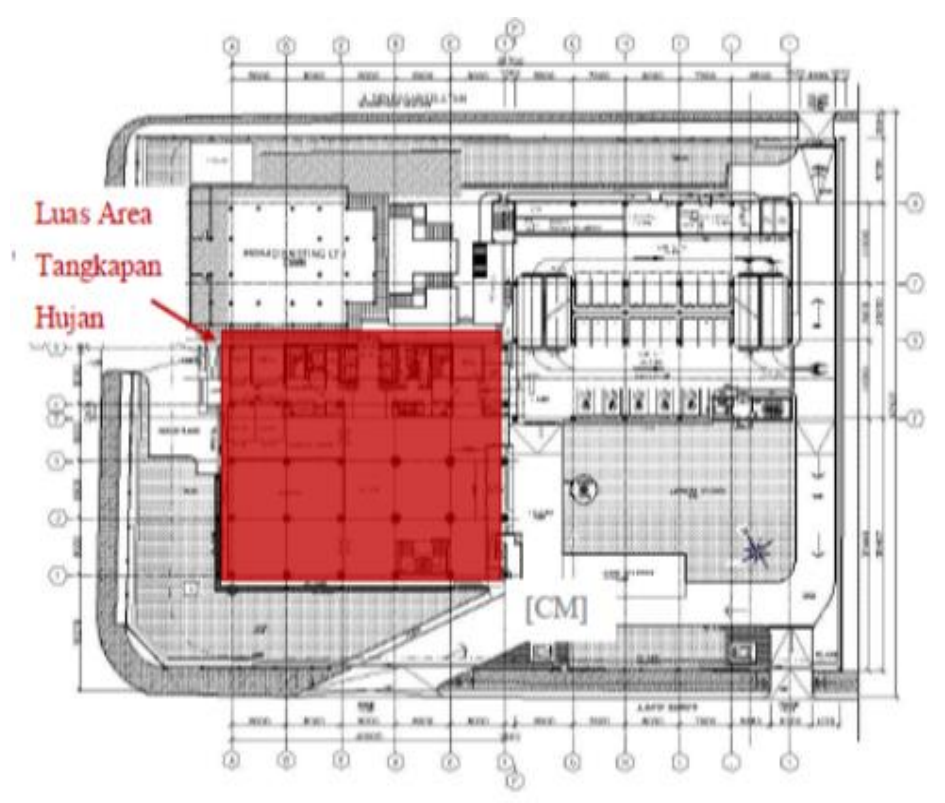

Gambar 2. Denah Atap Gedung Kantor Dinas Pendidikan 
Luas atap gedung kantor $=\mathrm{P} \times \mathrm{L}$

$=(800 \mathrm{~cm} \times 3) \times(800 \mathrm{~cm} \times 4)$

$=2.400 \mathrm{~cm} \times 3.200 \mathrm{~cm}$

$=7.680 .000 \mathrm{~cm}^{2}$

$=768 \mathrm{~m}^{2}$

Berikut ini perhitungan kumulatif supply air hujan:

Curah hujan rata-rata 10 tahun $(M)=$ curah hujan tahun ke $(1+d s t 10) / 10$

$=1909,0+1973,0+2395,0+1274,1+1488,2+2528,1+2906,7+2168,6+2711,5+2152,010$

$=2150,64 \mathrm{~mm} /$ tahun $=\mathbf{2 , 1 5} \mathbf{~ m} /$ tahun

Volume ketersediaan air hujan(vsupply) :

$=$ Luas area penangkapan air hujan $\mathrm{x}$ curah hujan rata-rata $\times$ koefisien runoff

$=768 \mathrm{~m} 2 \times 2,15 \mathrm{~m} /$ tahun $\times 0,80$

\section{$=1.320,96 \mathrm{~m} 3 /$ tahun}

Hasil perhitungan dapat dilihat pada tabel dan grafik berikut.

Tabel 2. Neraca Air

\begin{tabular}{|c|c|c|c|c|c|c|}
\hline \multirow[t]{2}{*}{ Bulan } & $\begin{array}{c}\text { Curah } \\
\text { Hujan } \\
\text { rata- } \\
\text { rata }\end{array}$ & $\begin{array}{l}\text { Luas } \\
\text { area }\end{array}$ & \multirow[t]{2}{*}{$\begin{array}{c}\text { Koefisien } \\
\text { Rumoff }\end{array}$} & $\begin{array}{l}\text { Volume } \\
\text { ketersediaan } \\
\text { air hujan }\end{array}$ & $\begin{array}{c}\text { Kebutuhan } \\
\text { Air } \\
\text { Perbulan }\end{array}$ & \multirow{2}{*}{$\begin{array}{l}\text { Sisa } \\
\mathrm{m}^{3} \\
\end{array}$} \\
\hline & $\mathbf{m}$ & $\mathrm{m}^{2}$ & & $\mathbf{m}^{3}$ & $\mathbf{m}^{3}$ & \\
\hline Januari & 0.40 & 768 & 0.8 & 248.60 & 11.04 & 237.56 \\
\hline Februari & 0.40 & 768 & 0.8 & 243.74 & 9.6 & 234.14 \\
\hline Maret & 0.23 & 768 & 0.8 & 139.01 & 11.04 & 127.97 \\
\hline April & 0.16 & 768 & 0.8 & 99.34 & 10.56 & 88.78 \\
\hline Mei & 0.12 & 768 & 0.8 & 70.83 & 11.04 & 59.79 \\
\hline Juni & 0.13 & 768 & 0.8 & 76.82 & 10.56 & 66.26 \\
\hline July & 0.11 & 768 & 0.8 & 65.19 & 11.04 & 54.15 \\
\hline Agustus & 0.05 & 768 & 0.8 & 31.62 & 11.04 & 20.58 \\
\hline September & 0.10 & 768 & 0.8 & 58.48 & 10.56 & 47.92 \\
\hline Oltober & 0.11 & 768 & 0.8 & 66.81 & 11.04 & 55.77 \\
\hline November & 0.16 & 768 & 0.8 & 97.61 & 10.56 & 87.05 \\
\hline \multirow[t]{2}{*}{ Desember } & 0.20 & 768 & 0.8 & 123.31 & 11.04 & 112.27 \\
\hline & \multicolumn{3}{|c|}{ Jumlah } & 1321.36 & 129.12 & 1192.24 \\
\hline
\end{tabular}

Keterangan: Data curah hujan dari stasiun hujan Kemayoran Jakarta.

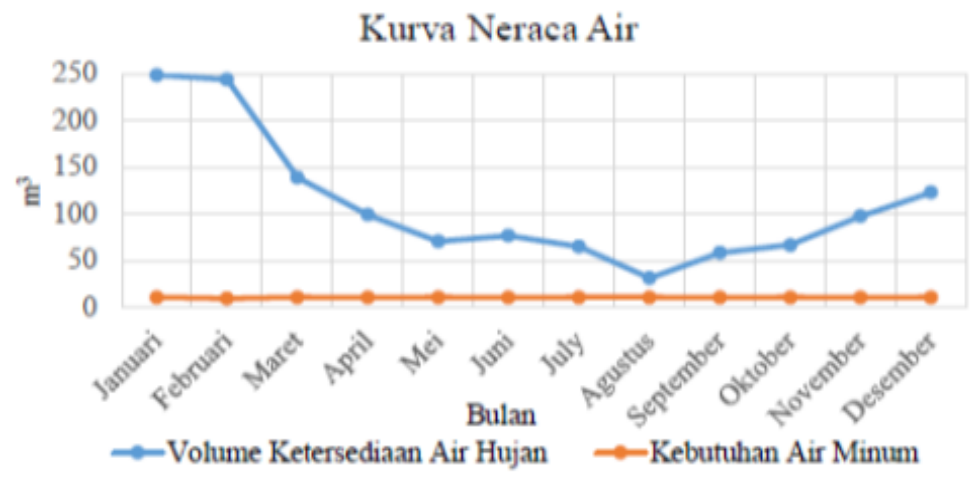

Gambar 3. Kurva Neraca Air

\subsection{Perencanaan Pemanfaatan Air Hujan Siap Minum}

Pada gedung kantor dan gedung parkir Dinas Pendidikan ini telah di desain sistem penyaluran air bersihnya dengan menggunakan metode tangki atap atau gravitasi. Pada perencanaan desain pemanfaatan air hujan ini menggunakan sistem pengaliran tangki atap atau gravitasi. Sistem ini merupakan yang paling menguntungkan karena pengoperasian dan pemeliharaannya yang mudah dilakukan, berbeda dengan sistem pengaliran pemompaan yang akan banyak memakan biaya besar karena pompa harus bekerja untuk setiap pengalirannya serta sistem tangki tekan yang perawatannya akan sulit ketika sistem 
mengalami kerusakan atau kekurangan tekanan. Berikut gambar eksisting sistem air bersih yang ada, dan gambar rencana sistem air minum.

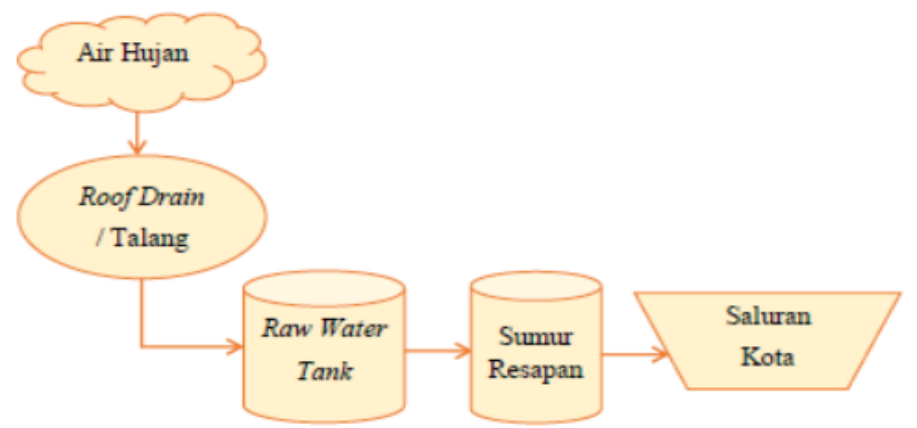

Gambar 4. Skema Sistem Air Hujan Eksisting

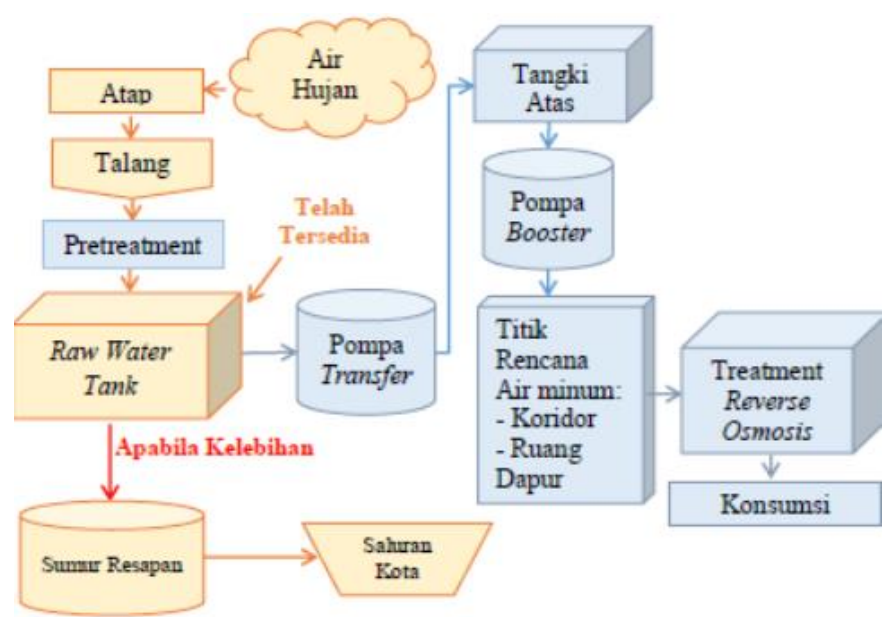

Gambar 5. Perencanaan Skema Sistem Pemanfaatan Air Hujan Alternatif 1

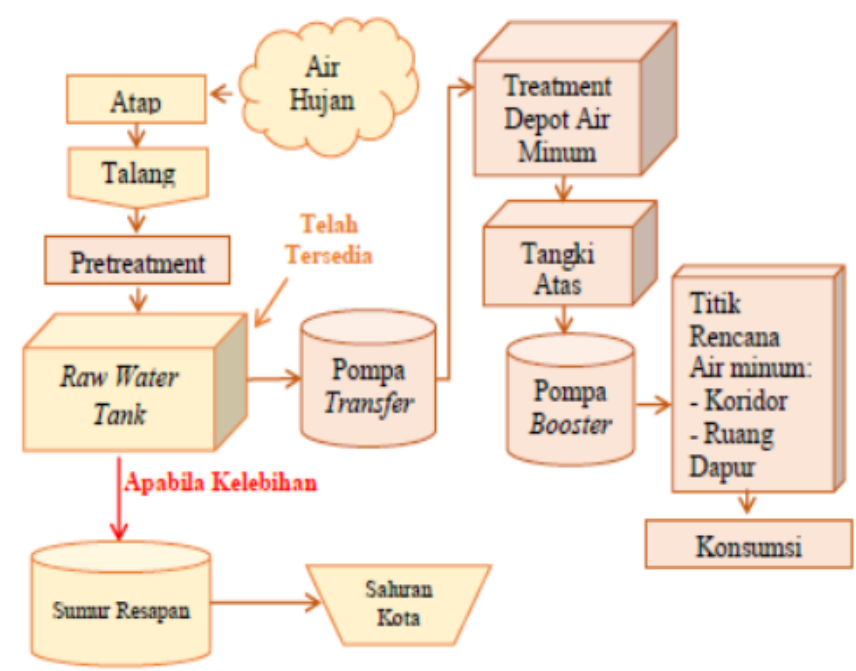

Gambar 6. Perencanaan Skema Sistem Pemanfaatan Air Hujan Alternatif 2

Gambar instalasi air bersih eksisting pada Gedung Kantor Dinas Pendidikan Provinsi DKI Jakarta dapat dilihat pada gambar berikut: 
Vol. 22, No. 2, Oktober 2020

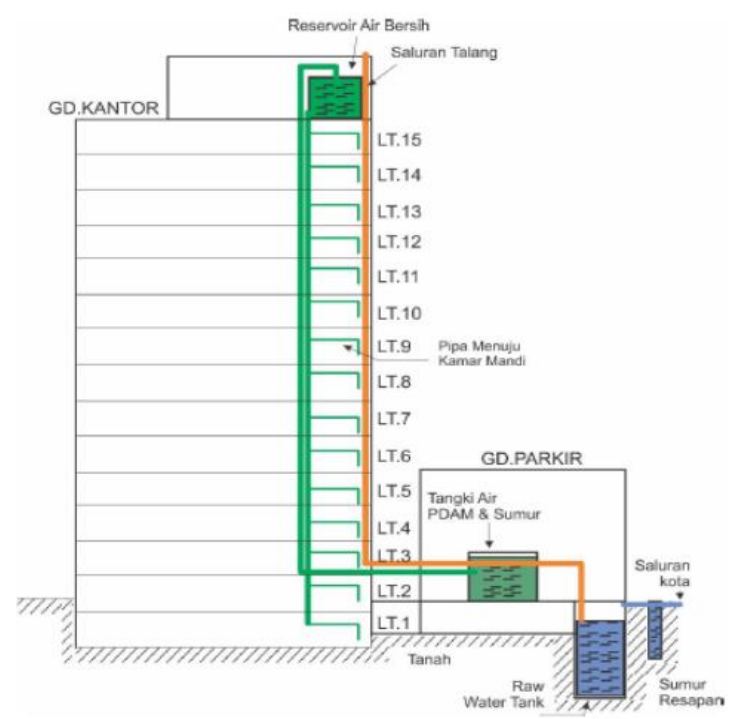

Gambar 7. Potongan Saluran Air Bersih Eksisting

Pada perencanaan desain pemanfaatan air hujan ini menggunakan sistem pengaliran tangki atap atau gravitasi. Sistem ini merupakan yang paling menguntungkan karena pengoperasian dan pemeliharaannya yang mudah dilakukan

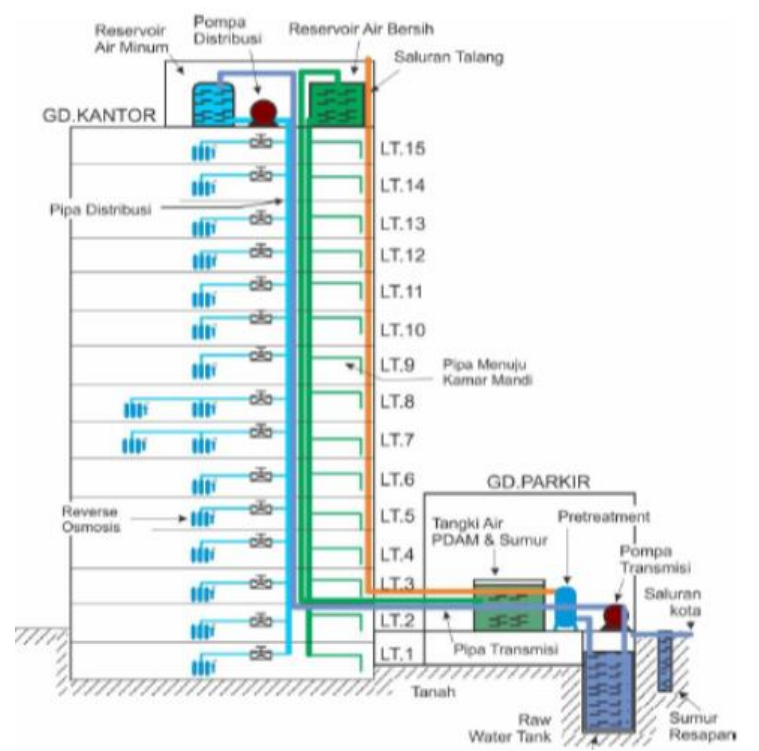

Gambar 8. Potongan Sistem Saluran Secara Keseluruhan

\subsection{Perencanaan Bak Penampung Air Hujan}

Untuk bak penampung air hujan memanfaatkan bak yang ada, dimensi bak penampungan sebesar $(\mathrm{L}=5 \mathrm{~m}, \mathrm{P}=7 \mathrm{~m}, \mathrm{~T}=4 \mathrm{~m})$.

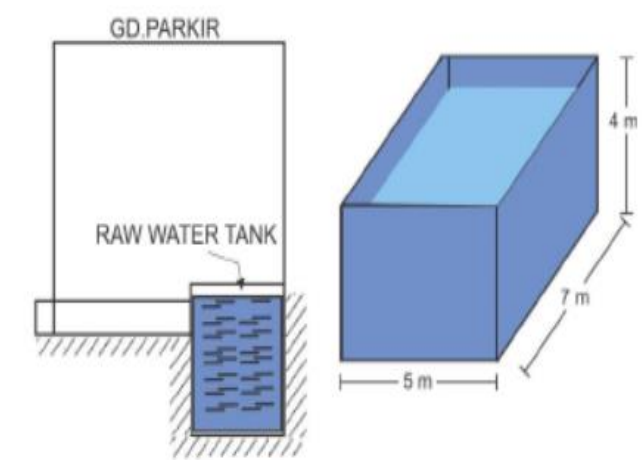

Gambar 9. Bak Penampung Air Hujan 
Untuk perhitungan volume bak penampung air baku ada di bawah ini:

$\mathrm{V}$ raw water tank $($ Eksisting $)=7 \mathrm{~m} \times 5 \mathrm{~m} \times 4 \mathrm{~m}=\mathbf{1 4 0} \mathbf{~ m}^{\mathbf{3}}$. V kebutuhan baku $=$ kebutuhan air dalam 1 bulan $\times$ musim kemarau. Musim kemarau $=6$ bulan $=11,56 \mathrm{~m}^{3} /$ bulan $\times 6$ bulan $=\mathbf{6 9 , 3 6} \mathbf{~ m}^{\mathbf{3}}$.

Maka, kebutuhan bak air baku adalah $69,36 \mathrm{~m}^{3}$

Volume ketersediaan raw water tank: Volume Kebutuhan Air baku $140 \mathrm{~m} 3: 69.36 \mathrm{~m}^{3}$

VRAW : VAir Baku Maka VRAW > VAir Baku

Sehingga penampungan eksisting sebesar $140 \mathrm{~m}^{3}$ adalah dimensi yang sudah dapat memenuhi kebutuhan air baku untuk air minum di kantor.

\subsection{Perencanaan Reservoir Air Minum}

Rencana reservoir ini berlokasi di ruang tangki air di atas lantai 15 yang bersebelahan dengan reservoir air bersih, sehingga tangki tidak terpengaruh akan kondisi cuaca yang ekstrem dan usia tangki akan lebih lama.

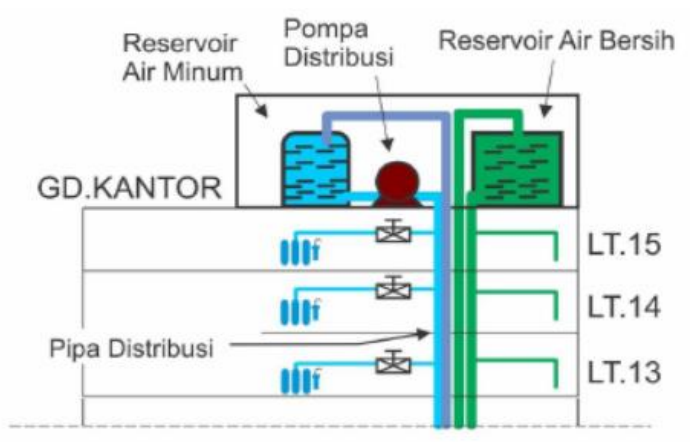

Gambar 10. Lokasi Reservoir Air Minum

Spesifikasi Reservoir :

Merk = Tangki air stainless Profil SS 304 Glossy

Tinggi $=1.780 \mathrm{~mm}$

Diameter $=1.430 \mathrm{~mm}$

Kapasitas $=2.550$ liter

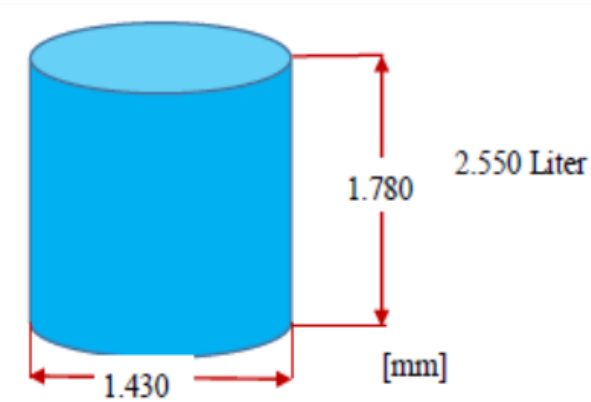

Gambar 11. Gambar Rencana Reservoir Air Minum

\subsection{Perencanaan Filter Air}

Untuk mengubah air hujan ini menjadi air baku, maka perlu adanya treatment awal atau pretreatment. Pretreatment dilakukan sebelum air hujan masuk ke dalam bak penampung awal atau raw water tank.
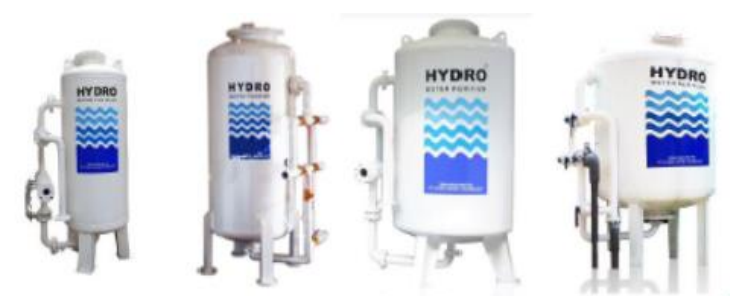

Gambar 12. Pretreatment Single Tangki 
Setelah air hujan terkumpul pada raw water tank yang telah direncanakan, langkah selanjutnya adalah merencanakan pengolahan air atau water treatment dengan alat pemurni air dengan reverse osmosis (RO) untuk menjadikan air hujan sebagai air siap minum yang dapat dikonsumsi orang-orang di Kantor Dinas Pendidikan DKI Jakarta. Reverse Osmosis yaitu menggabungkan mekanisme sistem fisika dan kimia secara modern yang dibantu dengan teknologi masa kini yang menghasilkan kualitas air bersih, sehat, dan mutu yang terjamin. Alat didesain secara ringkas (compact), pengoperasian dan pemeliharaan yang mudah (user friendly), disesuaikan dengan kebutuhan dan penempatannya.

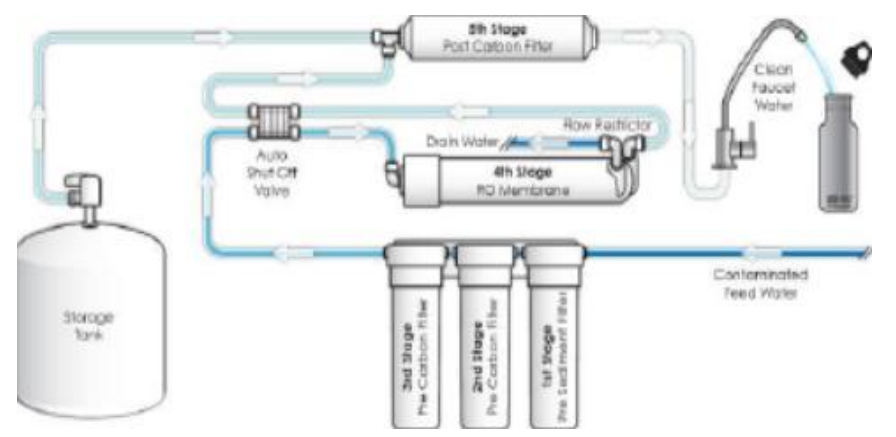

Gambar 13. Skema Proses Penjernihan RO

Produksi air yang di hasilkan harus memenuhi standar air baku yang berlaku di Indonesia.

Tabel 3. Standar kualitas air minum

\begin{tabular}{|c|c|c|}
\hline Parameter & Satuan & $\begin{array}{c}\text { Kadar Maksimum yang } \\
\text { diperbolehkan }\end{array}$ \\
\hline FISIKA & & \\
\hline Warna & TCU & 15 \\
\hline Temperatur & ${ }^{\circ} \mathrm{C}$ & Suhu udara $\pm 3{ }^{\circ} \mathrm{C}$ \\
\hline Kekeruhan & NTU & 5 \\
\hline Total zat padat terlarut (TDS) & $\mathrm{mg} / \mathrm{l}$ & 500 \\
\hline Rasa dan bau & & Tidak berasa dan berbau \\
\hline KIMIA & & \\
\hline Alumunium & $\mathrm{mg} / \mathrm{l}$ & 0,2 \\
\hline Tembaga & $\mathrm{mg} / \mathrm{l}$ & 2 \\
\hline Ammonia & $\mathrm{mg} / \mathrm{l}$ & 1,5 \\
\hline Klorida & $\mathrm{mg} / \mathrm{l}$ & 250 \\
\hline Kesadahan & $\mathrm{mg} / \mathrm{l}$ & 500 \\
\hline Besi & $\mathrm{mg} / \mathrm{l}$ & 0,3 \\
\hline Mangan & $\mathrm{mg} / \mathrm{l}$ & 0,4 \\
\hline $\mathrm{pH}$ & - & $6,5-8,5$ \\
\hline Sulfat & $\mathrm{mg} / \mathrm{l}$ & 250 \\
\hline Seng & $\mathrm{mg} / \mathrm{l}$ & 3 \\
\hline BIOLOGI & & \\
\hline E.Coli atau fecat coli & Jumlah per $100 \mathrm{ml}$ sampel & 0 \\
\hline Total Bakteri Coliform & Jumlah per $100 \mathrm{ml}$ sampel & 0 \\
\hline
\end{tabular}

Sumber : PERMENKES Nomor 492, 2010

\subsection{Rencana Anggaran Biaya}

Biaya yang direncanakan merupakan biaya yang dihitung dari bahan, alat dan upah untuk pemasangan perencanaan instalasi air siap minum di Gedung Kantor Dinas Pendidikan DKI Jakarta. Rekapitulasi dapat dilihat pada tabel berikut. 
Vol. 22, No. 2, Oktober 2020

Tabel 4. Rekapitulasi Biaya Perencanaan Sistem Pemanfaatan Air Hujan

\begin{tabular}{|c|l|r|r|}
\hline NO & URAIAN PEKERJAAN & & JULAH HARGA \\
\hline I & PEKERJAAN PEMBONGKARAN & $\mathrm{Rp}$ & $1.457 .210,00$ \\
\hline II & PEKERJAAN PELAT LANTAI DASAR & $\mathrm{Rp}$ & $653.660,00$ \\
\hline III & $\begin{array}{l}\text { PEKERJAAN INSTALASI AIR SIAP } \\
\text { MINUM }\end{array}$ & $\mathrm{Rp}$ & $428.854 .650,00$ \\
\hline IV & PEKERJAAN FINISHING & $\mathrm{Rp}$ & $17.076 .210,00$ \\
\hline V & PEKERJAAN ELEKTRIKAL & $\mathrm{Rp}$ & $3.445 .600,00$ \\
\hline & SUB TOTAL & $\mathrm{Rp}$ & $451.487 .330,00$ \\
\hline & PPN 10\% $\%$ & $\mathrm{Rp}$ & $45.148 .733,00$ \\
\hline & TOTAL & $\mathrm{Rp}$ & $496.636 .063,00$ \\
\hline & DIBULATKAN & $\mathrm{Rp}$ & $496.636 .000,00$ \\
\hline
\end{tabular}

Terbilang : Empat Ratus Sembilan Puluh Enam Juta Enam Ratus Tiga Puluh Enam Ribu Rupiah

\subsubsection{Perhitungan Biaya Memakai Dispenser}

Kantor Dinas Pendidikan Provinsi DKI Jakarta dalam memenuhi kebutuhan air minum, selama ini menggunakan dispenser, biaya yang dibutuhkan untuk pengadaan ini dapat dilihat pada tabel di bawah ini.

Tabel 5. Rekap Biaya pengadaan air Dispenser

\begin{tabular}{|c|c|c|c|c|c|c|c|c|c|}
\hline$\frac{\mathrm{Thh}}{\mathrm{Ka}}$ & $\frac{\text { Burp Galon }}{\text { Roseng }}$ & $\begin{array}{l}\text { Harp is } \\
\text { uing pilos } \\
\text { per thin }\end{array}$ & $\frac{\text { Ban }}{\text { larjo }}$ & $\begin{array}{l}\text { Burg } \\
\text { Dispenser per } \\
\text { tnhe }\end{array}$ & $\frac{\text { Bingz }}{\text { Disuloui }}$ & $\frac{\text { Upah }}{\text { Pegnoni }}$ & $\begin{array}{l}\text { Pertulno } \\
\text { Dispensar } \\
\text { Pertakn }\end{array}$ & $\begin{array}{l}\text { Tocai Harp } \\
\text { Reburihn } \\
\text { Perntrn }\end{array}$ & Krulitif \\
\hline ke & Pg & 20 & Ban & $\mathrm{Rp}$ & $\mathrm{Bg}$ & $\mathrm{Rg}$ & $8 p$ & 80 & $\mathrm{Rg}$ \\
\hline 1 & 35.000 & 17000 & 276 & 350000 & $1110-20.000$ & 60000000 & 105.000 & 355794578 & 355.794678 \\
\hline 2 & 36225 & 17595 & 276 & 322250 & 115920000 & 66000000 & 103.675 & 363551817 & 719346494 \\
\hline 3 & 37.493 & 182211 & 276 & $37+929$ & 121.716 .000 & 72.500 .000 & 112479 & 382304930 & 1101651.44 \\
\hline 4 & 38805 & 18S48 & 276 & 383.051 & 127801.300 & 79.8600000 & 116415 & 402230343 & 1.503 .831 .757 \\
\hline 5 & 40.163 & 19568 & 276 & 421633 & 140.581 .950 & 87.146000 & 120.490 & 440128391 & 1.944010 .158 \\
\hline 6 & 4156 & 20191 & 276 & 415.690 & 147.611079 & 96.630 .600 & 124707 & 452660366 & 2336.6785 .4 \\
\hline 7 & 43.024 & 20897 & 276 & 430.239 & 154991.633 & 106.293 .660 & 129.072 & 477006914 & 2873.635 .438 \\
\hline 8 & 44529 & 21.629 & 276 & 45298 & 162741.215 & 116923026 & 133569 & 502936119 & 3376.621 .557 \\
\hline 9 & 46008 & 22356 & 276 & 450.803 & 170.178 .275 & 128.615399 & 138265 & 530579998 & 3907201554 \\
\hline 10 & 47.701 & 23169 & 276 & 477.014 & 157966.103 & $141+75861$ & 143.104 & 580.376 .643 & 4.48078198 \\
\hline
\end{tabular}

\subsubsection{Perhitungan Biaya Metode RO}

Dengan menggunakan metode Reserve Osmosis (RO) dapat dilihat pada tabel berikut:

Tabel 6. Rekap Perhitungan Biaya Metode RO

\begin{tabular}{|c|c|c|c|c|c|c|}
\hline Tahun & $\begin{array}{c}\text { Biaya } \\
\text { Perencanann } \\
\text { Awal }\end{array}$ & $\begin{array}{l}\text { Upah } \\
\text { pegaxai }\end{array}$ & $\begin{array}{l}\text { Biaya } \\
\text { Listrik }\end{array}$ & $\begin{array}{c}\text { Harga } \\
\text { Perawatan } \\
\text { RO }\end{array}$ & $\begin{array}{c}\text { Total Harga } \\
\text { Reburuhan } \\
\text { Pertahun }\end{array}$ & Kumulatif \\
\hline $\mathrm{Ke}$ & $\mathrm{Rp}$ & $\mathrm{Rp}$ & $\mathrm{Rp}$ & $\mathrm{Rp}$ & $R p$ & $\mathrm{Rp}$ \\
\hline 1 & 496.636 .000 & 72.000 .000 & 8.654 .308 & 0 & 577290308 & 577290308 \\
\hline 2 & 0 & 79.200 .000 & 8957.208 & 0 & 88.157 .208 & 665.447 .516 \\
\hline 3 & 0 & 87.120 .000 & 9270.711 & 0 & 96.390 .711 & 761.838 .227 \\
\hline 4 & 0 & 95.832 .000 & 9595.186 & 0 & 105.427 .186 & 867.265 .412 \\
\hline 5 & 0 & 105.415 .200 & 9931.017 & 2.454 .739 & 117.800 .956 & 985.066 .368 \\
\hline 6 & 0 & 115.956 .720 & 10.278 .603 & 0 & 126.235 .323 & 1.111301 .691 \\
\hline 7 & 0 & 127.552 .392 & 10.638 .354 & 0 & 138.190 .746 & 1.249 .492 .437 \\
\hline 8 & 0 & 140.307 .631 & 11.010 .696 & 0 & 151.318 .327 & 1.400 .810 .764 \\
\hline 9 & 0 & 154.338 .394 & 11.396 .071 & 0 & 165.734 .465 & 1.566 .545 .229 \\
\hline 10 & 0 & 169.772 .234 & 11.794 .933 & $2.915,460$ & 184.482 .626 & 1.751 .027 .855 \\
\hline
\end{tabular}

Dari hasil perhitungan biaya menggunakan dispenser dan dibandingkan dengan metode RO dapat dilihat pada tabel berikut: 


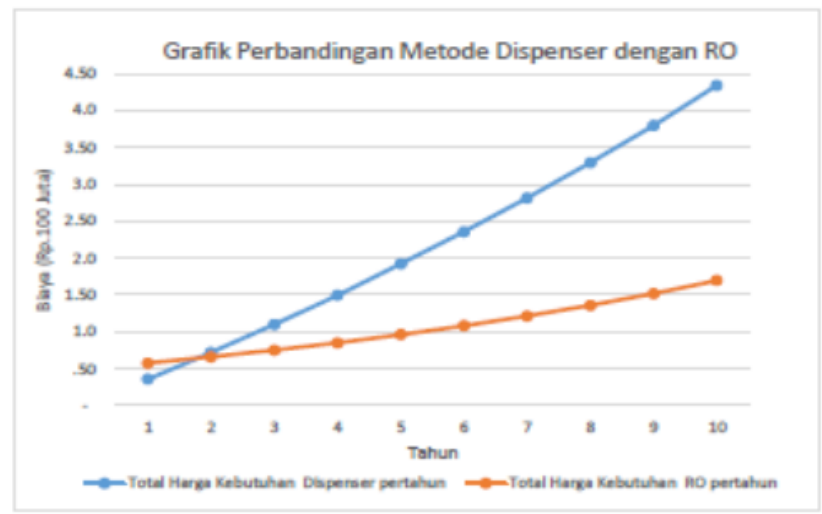

Gambar 14. Grafik Perbandingan Metode

Tabel 7. Persentase Penghematan Antara Metode RO dan Metode Galon

\begin{tabular}{|c|c|c|c|c|}
\hline Tahun & $\begin{array}{c}\text { Biaya Kumulatif } \\
\text { Metode Galon (Rp) }\end{array}$ & $\begin{array}{c}\text { Biaya Kumulatif } \\
\text { Metode RO (Rp) }\end{array}$ & $\begin{array}{c}\text { Penghematan } \\
(\mathrm{Rp})\end{array}$ & $\begin{array}{c}\text { Penghematan } \\
\text { dalam (\%) }\end{array}$ \\
\hline 1 & $355,794,678$ & $572,449,763$ & $-216,655,085$ & -60.9 \\
\hline 2 & $717,690,494$ & $655,597,007$ & $62,093,487$ & 8.7 \\
\hline 3 & $1,096,542,664$ & $746,802,405$ & $349,740,259$ & 31.9 \\
\hline 4 & $1,493,373,661$ & $846,862,792$ & $646,510,869$ & 43.3 \\
\hline 5 & $1,919,606,611$ & $959,109,111$ & $960,497,500$ & 50.0 \\
\hline 6 & $2,355,784,466$ & $1,079,595,385$ & $1,276,189,081$ & 54.2 \\
\hline 7 & $2,813,509,535$ & $1,211,835,865$ & $1,601,673,670$ & 56.9 \\
\hline 8 & $3,294,164,070$ & $1,356,995,667$ & $1,937,168,402$ & 58.8 \\
\hline 9 & $3,799,241,510$ & $1,516,356,059$ & $2,282,885,451$ & 60.1 \\
\hline 10 & $4,342,615,918$ & $1,694,241,519$ & $2,648,374,399$ & 61.0 \\
\hline
\end{tabular}

\section{KESIMPULAN DAN SARAN}

\subsection{Kesimpulan}

Dari hasil perencanaan sistem pemanfaatan air hujan sebagai air siap minum, didapatkan kesimpulan bahwa air hujan dapat dimanfaatkan sebagai air siap minum serta dapat diaplikasikan untuk gedung Dinas Pendidikan Provinsi DKI Jakarta. Dengan penghematan biaya pada periode tahun kedua yang telah mendapatkan keuntungan sebesar 8,7\% menggunakan sistem Reverses Osmosis.

\subsection{Saran}

1. SOP (Standar Operasional Prosedur) perlu dibuat untuk penggunaan alat water treatment reverse osmosis agar semua yang menggunakan akan lebih mudah juga terawat dan terkendali.

2. Sebelum adanya pelaksanaan metode ini sebaiknya diadakan penelitian dari kualitas air hujan lebih lanjut untuk digunakan sebagai air baku untuk air siap minum di gedung kantor tersebut.

\section{DAFTAR PUSTAKA}

[1] Badan Standardisasi Nasional. 2015. Sistem PlambingPada Bangunan Gedung

[2] Darmasetiwan, Martin. 2001. Teori dan. Perencanaan Instalasi pengolahan Air. Yayasan Suryono. Bandung

[3] Dede Juliansyal. 2015. Analisis Curah Hujan. Serang: Universitas Sultan Agung Tirtayasa

[4] Departemen Kesehatan (2002).Keputusan Menteri Kesehatan RI No. 907/MENKES/SK/VII/2002 tentang Syarat-syarat dan Pengawasan Kualitas Air Minum. Jakarta.

[5] Effendi, H. 2003. Telaah kualitas air. Kanisius. Yogyakarta.

[6] Hakim, Arif Rahman. 2016. Perencanaan Sistem Pemanfaatan Air Hujan dan Air Daur Ulang Di Apartemen Sheerwood Residence Kelapa Gading Jakarta Utara. Bandung : Politeknik Negeri Bandung.

[7] Peraturan Gubernur Provinsi Daerah Khusus Ibukota Jakarta Nomor 38 Tahun 2012. Tentang Bangunan Gedung Hijau

[8] Prayoga,Firman.2017. Perencanaan Pemanfaatan Air Hujan Sebagai Air Siap Minum di Lingkungan Politeknik Negeri Bandung. Bandung : Politeknik Negeri Bandung

[9] Pratomo, Agit. 2017. Kritisnya Kualitas Air Tanah di Jakarta.

[10] Syahputra, KH. 2017. Perencanaan Sistem Pemanfaatan Air Hujan Pada Mall 23 Paskal Bandung. Bandung : Politeknik Negeri Bandung 